\title{
The Bengali Pharaoh: Upper-Caste Aryanism, Pan-Egyptianism, and the Contested History of Biometric Nationalism in Twentieth-Century Bengal
}

\author{
PROJIT BIHARI MUKHARJI \\ Department of History and Sociology of Science, University of Pennsylvania
}

\section{IN T R O DU C T I O N}

Today "raciology," in its new genomic avatar, is once again on the rise. ${ }^{1}$ Generations of humanists have insisted that "race" is only a "social construct," but some scholars and scientists are now rethinking or rejecting this view. What is more, many of the most enthusiastic exponents of the new raciology are based outside the Minority World. Countries like Mexico, South Africa, and India are major players in genomic studies that operationalize new genomic forms of race. ${ }^{2}$ How did we get here? Raciology made a comeback while we were happy in the belief that it had disappeared, but did it ever really go away? Was the reemergence of raciology in the postcolony inevitable? Must human

Acknowledgments: An earlier version of this paper was presented at the South Asia Conference at Madison in 2015. I am grateful to the many comments and suggestions I received on that occasion. Thomas Trautmann and Chris Fuller's suggestions and encouragement were particularly helpful. The feedback I received from the anonymous CSSH referees was both generous and productive. Finally, I must acknowledge Manjita Mukharji's patience in reading multiple drafts of this paper.

1 Nadia Abu El-Haj, "The Genetic Reinscription of Race," Annual Review of Anthropology 36 (2007): 283-300; Pamela Sankar, "MEDLINE Definitions of Race and Ethnicity and their Applications to Genetic Research," Nature Genetics 34, 2 (2002): 119; Nikolas Rose, "Race, Risk and Medicine in the Age of "Your Own Personal Genome,"' BioSocieties 3 (2003): 423-39; Michael Montoya, "Bioethnic Conscription: Genes, Race and Mexicana/o Ethnicity in Diabetes Research," Current Anthropology 22, 1 (2007): 94-128; Ann Morning, The Nature of Race: How Scientists Think and Teach about Human Difference (Berkeley: University of California Press, 2011); Dorothy E. Roberts, Fatal Invention: How Science, Politics and Big Business Re-Create Race in the Twenty-First Century (New York: New Press, 2011).

2 Ruha Benjamin, "A Lab of Their Own: Genomic Sovereignty as Postcolonial Science Policy," Policy and Society 28 (2009): 341-55. 
difference be imagined as one or the other form of somatic difference? The time has come to ask these and related questions.

Historians of colonialism in general and the British Empire in South Asia in particular have produced many fascinating accounts of imperial raciology. Today, anyone who has taken undergraduate classes in the history of British India has encountered the towering figure of Sir Herbert Hope Risley and his notorious "nasal index." "There are also broader cultural accounts of the role of race and raciology in British imperial knowledge. ${ }^{4}$ But few such studies extend chronologically beyond the Great War or sociologically beyond the British administrative elite. ${ }^{5}$

As David Arnold points out, "race" was never a "relatively homogeneous set of ideas and practices, driven by material greed and social anxieties in the West, and capable of delivering social power and political authority to whites across the globe." It was always a far more "nebulous and self-contradictory concept" that was frequently "internalized and reworked" by the very people who were subjects of European racial discourse. ${ }^{6}$ To understand the reemergence of raciology in the present genomic age, we must better understand this process of "internalization and reworking." As important and consequential as imperial raciologies remain, there is a gaping scholarly hole regarding late colonial and postcolonial national raciologies, and we urgently need to turn our critical eye toward them. This is what I undertake in the present article.

My intentions here are threefold. First, I describe the long afterlives of Risleyan raciology in late colonial and postcolonial Bengal. In so doing, I highlight the direct institutional and intellectual genealogies that connect Risley, his early Indian inheritors, and the present generation of genomicists. Second, I map the diverse interests, agendas, and nationalisms that these post-Risleyan raciologies have served. Here I examine the conspicuous "public life" of raciology that helped the post-Risleyan version sink deep roots in the postcolonial Bengali imaginary. Finally, I detail an alternative approach for thinking about group-based human difference that did not somaticize it. Craftology, as this other imagination of group-based human difference came to be called, drew

3 Thomas R. Metcalf, Ideologies of the Raj (Cambridge: Cambridge University Press, 1995); Nicholas Dirks, Castes of Mind: Colonialism and the Making of Modern India (Princeton: Princeton University Press, 2001); Crispin Bates, Race, Caste and Tribe in Central India: The Early Origins of Indian Anthropometry (Edinburgh: Edinburgh Papers in South Asian Studies, 1995); Thomas Trautmann, Aryans and British India (Berkeley: University of California Press, 2010).

4 Peter Robb, ed., The Concept of Race in South Asia (Delhi: Oxford University Press, 1997); Mrinalini Sinha, Colonial Masculinity: The 'Manly Englishman' and the 'Effeminate Bengali' in the Late Nineteenth Century (Manchester: Manchester University Press, 1995).

5 For an exception, see Projit Bihari Mukharji, "From Serosocial to Sanguinary Identities: Caste, Transnational Race Science and the Shifting Metonymies of Blood Broup B, India c. 1918-1960," Indian Economic and Social History Review 51, 2 (2014): 143-76.

6 David Arnold, “'An Ancient Race Outworn': Malaria and Race in Colonial India, 18601930," in Waltraud Ernst and Bernard Harris, eds., Race, Science and Medicine (London: Routledge, 1999), 123-43, 123. 
upon a diverse set of influences, the most important being a Bengali tradition of Egyptology.

Egyptology left an enormous cultural footprint upon the modern world. Its history is linked to the emergence of several key modern academic disciplines ranging from evolutionary biology to archaeology, and it also featured prominently in art, literature, and the cinema. Yet, thus far its impact has been explored almost exclusively in relation to modern Egypt and the imperial West, and its influences upon other areas of the world, such as South Asia, have been utterly neglected. As I will show in what follows, Egyptology was a significant presence in Bengal, where it played a prominent role in shaping ideas about race and history.

The key figure through whom Bengali Egyptology intersects with mid-twentieth-century Bengali raciology is the enigmatic Bengali Pharaoh. This figure of an exiled Egyptian pharaoh who had settled in Bengal with his followers, though dismissed by Egyptologists and archaeologists, was nurtured by artists and folklorists seeking an alternative to the pervasive Aryanism that shaped the historical self-identity of Bengali upper castes. Despite the seemingly flimsy ground upon which the Bengali Pharaoh stands, he embodies an important alternate imaginary, one that interrupts the teleology connecting imperial raciology to modern genomic raciology via mid-twentieth-century upper-caste Aryanism. The writings and controversies surrounding the Bengali Pharaoh draw our attention to an attempt to conceptualize group-based human difference in non-somatic ways. As I briefly describe in the conclusion, in Bengal such alternative imaginaries remain current outside the formal academy, despite the disdain of mainstream scholars.

\section{BIOMETRIC NATIONALISM}

Overturning the historiographic importance granted to Risley's raciology, C. J. Fuller has recently pointed out that in fact it had little impact upon British colonial policies. ${ }^{7}$ In stark contrast to its seemingly stillborn career within the imperial administrative apparatus, however, Risleyan raciology had a robust and fulsome life in nationalist circles, which, following Dipesh Chakrabarty, I call its "public life." Chakrabarty distinguishes between the "public" and the "cloistered" lives of scholarly knowledges. ${ }^{8}$ While a discipline's "cloistered" life is restricted to university classrooms, professional associations, academic conferences, and so forth, its "public" lives are much more chaotic and disorganized. This distinction is immensely useful for thinking about the history of anthropometry in Bengal.

7 C. J. Fuller, “Anthropologists and Viceroys: Colonial Knowledge and Policy Making, 1870 1911," Modern Asian Studies 50, 1 (2016): 1-42.

8 Dipesh Chakrabarty, The Calling of History: Sir Jadunath Sarkar and His Empire of Truth (Chicago: University of Chicago Press, 2015). 
Anthropometry's public life in Bengal commenced soon after the publication of Risley's 1901 Census Report. A young schoolmaster at the famous Hindu School in Calcutta, Ramprasad Chandra, was piqued by Risley's description of Bengalis as being of Mongolo-Dravidian origin, and he decided to refute Risley by collecting and analyzing his own data. Over the next few years, Chanda, while continuing his day job as a schoolmaster, gathered data and published anthropometric studies in a Bombay-based journal called East and West. In 1905 he was transferred to the Rajshahi Collegiate School, and he played an important part in the second annual conference of the Bengal Literary Conference (Bangiya Sahitya Parishad) held at Rajshahi in 1909. ${ }^{9}$

At the meeting Chanda read a paper on the origins of the Bengali people based on his own anthropometric research. The paper struck a chord and the conference passed a resolution to support Chanda to undertake further study and publish a book on the subject. The following year, the Varendra Research Society was established in Rajshahi to further historical research in northern Bengal, and it undertook to support Chanda's work. ${ }^{10}$ His monograph The Indo-Aryan Races finally appeared in 1916 and was firmly grounded in anthropometric data. In the book Chanda deftly compared his own data with that collected by a number of other, mostly British anthropometry researchers, including Risley.

Along with Sasadhar Ray, Chanda had measured a number of "living subjects belonging to different sections of the Brahman caste" over several months in 1909 and 1910. They were aided in this work by a number of well-placed Bengali friends and acquaintances such as Surya Kumar Guha, the deputy superintendent of police in Rajshahi, and Hem Chanda Ganguly, a professor at the Rajshahi College. In 1910, Director of Public Instruction Mr. $\mathrm{H}$. Sharpe intervened and got the provincial government to relieve Chanda from his teaching duties for three months by putting him on "special duty for ethnological researches." 11 This official backing also enabled Chanda to borrow anthropometric instruments from the Ethnographic Survey of India. His involvement with the Varendra Research Society, on the other hand, earned him the support of a number of local aristocrats who backed its work, most notably the Maharaja of Dinajpur Sir Girijanath Ray, the Maharaja of Kasimbazar Sir Manindra Chanda Nandi, and Kumar Sarat Kumar Ray of Dighapatiya.

9 Ramprasad Chanda, The Indo-Aryan Races (Rajshahi: Varendra Research Society, 1916), ix-x.

${ }^{10}$ The Varendra Research Society was an enormously influential and productive scholarly association that conducted several archaeological surveys and excavations, besides publishing critical editions of old Sanskrit texts and a number of academic monographs and articles. It also established a museum of local antiquities. See Saifuddin Chowdhury, "Varendra Research Society," Banglapedia: National Encyclopedia of Bangladesh: http://en.banglapedia.org/index.php?title=Varendra Research_Society (accessed 21 Jan. 2016).

11 Chanda, Indo-Aryan Races, ix-x. 
With the exception of the three-month relief from teaching and the loan of a few instruments relatively late in the project, governmental involvement in this anthropometric venture was minimal. The project was driven forward by Bengali intellectuals and aristocrats using their own contacts and capitalChanda's anthropometric work was clearly a form of public anthropometry.

Around the same time as Chanda was undertaking his measurements, the eminent Bengali intellectual Sir Brajendranath Seal was invited to the Universal Races Congress in London. Organized by Gustave Spiller of the Ethical Culture Movement, the Congress brought together anthropologists, sociologists, politicians, lawyers, and students from across the world to discuss race relations between "East" and "West." Attendees included Sir Syed Ameer Ali, W.E.B. Du Bois, Mancherjee Bhownaggree, Annie Besant, and Margaret Noble (also known as "Sister Nivedita"). ${ }^{12}$

On 26 July 1911, Seal delivered the keynote address, entitled "The Meaning of Race, Tribe, Nation." He declared his unabashed faith in raciology as the route through which international conflict could be scientifically resolved. "A scientific study of the constituent elements and the composition of races and peoples," he iterated, "will alone point the way to a settlement of interracial claims and conflicts on a sound progressive basis, the solution of many an administrative problem in the composite United States and the heterogeneous British Empire, and even the scope and methods of social legislation in every modern State."13 In Seal's hands, then, raciology and anthropometry were no longer merely instruments to further the social ambitions of upper-caste Bengalis like Chanda; but were far-reaching means to create a new political settlement for the modern world.

Two of the most prominent young Bengalis to take up anthropometry in the following decade, Prasanta Chandra Mahalanobis and Biraja Shankar Guha, were both inspired by Seal. Mahalanobis, doyen of Indian statistics, was close to Seal through their common membership in a reformist faction of the Brahmo Samaj. Originally a physics student at Cambridge (though he left without taking a degree), Mahalanobis taught himself the then-new science of statistics on the ship home when World War I broke out. A chance meeting later with the zoologist Nelson Annandale led Mahalanobis in 1922 to apply his statistical methods to Annandale's study of the anthropometry of Calcutta's mixed-race population. ${ }^{14}$

\footnotetext{
12 "Universal Races Congress" (no author): http://www.open.ac.uk/researchprojects/makingbritain/content/universal-races-congress (accessed 21 Jan. 2016).

13 Brajendranath Seal, "Meaning of Race, Tribe, Nation," in G. Spiller, ed., Papers on InterRacial Problems (London: P. S. King \& Sons, 1911), 13.

14 Projit Bihari Mukharji, "Profiling the Profiloscope: Facialization of Race Technologies and the Rise of Biometric Nationalism in Inter-War British India," History and Technology 31, 4 (2015): 376-96; P. C. Mahalanobis, "Anthropological Observations of the Anglo-Indians of Calcutta: Part I-Analysis of Male Stature," Records of the Indian Museum 23 (1922): 1-96.
} 
Mahalanobis rose rapidly in the field and in 1925 he was invited to preside over the Anthropology Section of the Indian Science Congress. Resurrecting Risley for the Presidential Address, he argued that modern statistical analysis of Risley's data demonstrated its fundamental accuracy and usability. ${ }^{15}$ Mahalanobis published further research papers based exclusively on Risley's data in 1933, 1934, and $1941 .{ }^{16} \mathrm{He}$ posited that the only "serious objection" to Risley's work was that there were inconsistencies between his individual figures and his averages. Using advanced statistical tools, Mahalanobis argued that these errors had only crept in later, during tabulation, and were therefore superficial-Risley's basic data was singularly free of faults and therefore entirely accurate.

Mahalanobis' defense of Risley in the name of accuracy is reminiscent of more recent attempts by some anthropologists to redeem Samuel Morton's racialized craniometry after Stephen Jay Gould had held it up as a classic example of nineteenth-century race science. Such defenses, by making the issue one of precision, hide the overtly racialized assumptions behind the measurements. ${ }^{17}$ The problem is not whether someone correctly read the calipers placed on another man's nose, but rather whether the length of the nose should in the first place be considered a sign of some deeper, inheritable racial difference.

Mahalanobis' defense of Risley's work influenced a number of others, including D. N. Majumdar, to use Risley's data as well as to undertake new anthropometric surveys to produce data sets comparable with Risley's. Majumdar's Bengal Anthropometric Survey of 1945, undertaken even as the country and the province were in the midst of severe political turmoil, was instigated and enabled by Mahalanobis' personal interest in the matter. ${ }^{18}$ Today, many of those working on genomic studies of human variation in India who cite Risley as an intellectual pioneer work directly within the institutional and intellectual legacies left behind by Mahalanobis. ${ }^{19}$

15 P. C. Mahalanobis, "Analysis of Race-Mixture in Bengal," Journal of the Asiatic Society of Bengal 23 (1927): 301-33.

16 P. C. Mahalanobis, “A Revision of Risley's Anthropometric Data Relating to Tribes and Castes of Bengal," Sankhyā: The Indian Journal of Statistics 1, 1 (1933): 76-105; P. C. Mahalanobis, "A Revision of Risley's Anthropometric Data Relating to the Chittagong Hill Tribes," Sankhyā: The Indian Journal of Statistics 1, 2/3 (1934): 267-76; P. C. Mahalanobis and Chameli Bose, "Correlation between Anthropometric Characters in some Bengal Castes and Tribes," Sankhyā: The Indian Journal of Statistics 5, 3 (1941): 249-60.

17 On the Morton-Gould controversy and its problems, see Michael Weisberg, "Remeasuring Man," Development and Evolution 16, 3 (2014): 166-78.

${ }^{18}$ D. N. Majumdar, "Bengal Anthropometric Survey, 1945: A Statistical Study," Sankhyā: The Indian Journal of Statistics 19, 3/4 (1958): 201-408.

19 Partha P. Majumder, "People of India: Biological Diversity and Affinities," in D. Balasubramanian and N. Appaji Rao, eds., The Indian Human Heritage (Hyderabad: United Press, 1998), 45-59. 
Mahalanobis acknowledged his debt to Seal in taking up anthropometry, ${ }^{20}$ and Seal's influence on B. S. Guha was no less significant. Unlike Mahalanobis, who had no formal training in anthropometry or anthropology, Guha became the first South Asian to earn a Ph.D. in Anthropology, from Harvard University in $1924 .^{21}$ His application for admission to Harvard's graduate program mentioned Seal as one of the two "principal teachers" who had taught him at the Calcutta University as an undergraduate. ${ }^{22}$

Guha wrote his Ph.D. thesis on "The Racial Basis of the Caste System in India." Upon his return to India he initially joined the Zoological Survey of India before founding the Indian Anthropological Institute at Calcutta in 1936. In 1938, he presided over the anthropology sections of both the Indian Science Congress and the British Association for the Advancement of Science in Calcutta. That same year he acted as vice-president of the Physical Anthropology and Racial Biology Section of the International Congress of Anthropology in Copenhagen. Finally, just before the end of colonial rule in 1946, he convinced the government to create a separate Anthropological Survey of India along the lines of older governmental surveys such as the Trigonometric Survey, the Archaeological Survey, and the Zoological Survey. ${ }^{23}$

Mahalanobis, on the other hand, had gradually established a very different institutional base. Initially, while a teacher at the Presidency College in Calcutta, he set up a Statistical Laboratory within the College to pursue small, ad hoc projects that the government occasionally gave him. Later, in the early 1930s, along with two colleagues from the College, he established the Indian Statistical Institute. Though officially registered in 1932, the Institute remained physically based at the Presidency College until 1953, when it acquired its own campus. ${ }^{24}$

It is one of those delicious historical ironies that while the British imperial state of Risley's era had been reluctant to give a stable departmental home to Risleyan anthropometry, the almost-postcolonial state of the 1940s seemed far more sympathetic to Risleyan raciology. Today, both the Anthropological Survey of India and the Indian Statistical Institute are actively involved in conducting genomic surveys of the Indian population, and both are part of the Indian Genome Variation Consortium (IGVC). ${ }^{25}$ Partha Pratim Majumder, who represented the Indian Statistical Institute in the Consortium, was both a student and a professor at the Indian Statistical Institute. In a 1998 article

20 Mahalanobis, “Analysis of Race-Mixture," 324.

21 D. P. Sinha and Carleton S. Coon, "Biraja Sankar Guha, 1894-1961," American Anthropologist 65, 2 (1963): 382-87.

22 B. S. Guha, "Application for Admission to Candidacy in a Degree," Graduate School of Arts and Sciences, Harvard University Archives, UAV 161.201.10, box 42.

23 Sinha and Coon, "Biraja Sankar Guha."

24 C. Radhakrishna Rao, "Mahalanobis Era in Statistics," Sankhyā: The Indian Journal of Statistics, Series B (1961-2002) 35 (1973): 12-26.

${ }_{25}$ Indian Genome Variation Database Portal: www.igvdb.res.in (accessed 12 July 2016). 
explaining the basis of the genetic work, he acknowledged Risley as the earliest exponent of anthropometry in South Asia. While Majumder argued that, after the 1950s, the earlier typological agenda of anthropometry had given way to greater emphasis on the quantification of variation, he himself continued to use measurements that recalled Risleyan anthropometry, including the hallowed nasal index. ${ }^{26}$

Majumder's comments echo a public perception that scientific raciology had disappeared after World War II, but historians have increasingly disproved this. There were some crucial changes to raciology, but the continuities remained strong. Preeminently, a highly somaticized idea of inheritable groupbased human difference survived, though it now serves distinctly neoliberal political and economic rationales. ${ }^{27}$ This continuity is not peculiar to India. A growing number of scholars have pointed out that, despite some important changes, throughout the world the new, postwar raciology retained significant continuities with the prewar forms. New disciplines, like population genetics, replaced older ones like physical anthropology, ${ }^{28}$ and an essence-based idea of "race" was replaced by a frequency-based notion of "population." 29 New forms of measurements, such as blood group frequencies, supplemented older nasal indices. ${ }^{30}$ Nonetheless, through all of this change a fundamental idea of inheritable, group-based, somatic difference was retained. Warwick Anderson observes that racial thinking has likewise retained a powerful presence in the mundane everydayness of contemporary medical school curricula. ${ }^{31}$ Similar shifts and continuities have been documented in the United States, the United Kingdom, Israel, Australia, and many other parts of the world. ${ }^{32}$

26 Majumder, "People of India."

27 El-Haj, "Genetic Reinscription."

28 Veronika Lipphardt, "Geographical Distribution Patterns of Various Genes: Genetic Studies of Human Variation after 1945," Studies in the History and Philosophy of Biological and Biomedical Sciences 47 (2001): 50-61.

29 Jenny Reardon, Race to the Finish: Identity and Governance in an Age of Genomics (Princeton: Princeton University Press, 2005), 65.

30 For blood groups in India, see Projit Bihari Mukharji, "From Serosocial to Sanguinary Identities: Caste, Transnational Race Science and the Shifting Metonymies of Blood Group B, India c. 1918-1960," Indian Economic and Social History Review 51, 2 (2014): 146-73. For a more global account of blood groups, see Jenny Bangham, "Blood Groups and Human Groups: Collecting and Calibrating Genetic Data after World War Two," Studies in the History and Philosophy of Biological and Biomedical Sciences 47 (2014): 74-86.

31 Warwick Anderson, "Teaching 'Race' at Medical School: Social Scientists on the Margin," Social Studies of Science 38, 5 (2008): 785-800.

32 See Emma Kowal, "Orphan DNA: Indigenous Samples, Ethical Biovalue and Postcolonial Science," Social Studies of Science 43, 4 (2013): 577-97; Snait B Gissis, "When Is 'Race' a Race? 1946-2003," Studies in the History and Philosophy of Biological and Biomedical Sciences 39, 4 (2008): 437-50; Soraya de Chadarevian, "Chromosome Surveys of Human Populations: Between Epidemiology and Anthropology," Studies in the History and Philosophy of Biological and Biomedical Sciences 47 (2014): 87-96. 
One conspicuous aspect of the new, mid-twentieth century raciology was the vastly expanded set of biomarkers to be counted. Superficial features like height, nasal length, eye color, and the like were now supplemented by biomarkers invisible to the naked eye such as blood groups, cell enzymes, and genes. Anthropometry thus gradually evolved into biometry, while "biometric nationalism" emerged as a much more politically plastic assemblage of an everexpanding repertoire of raciological techniques and varied forms of nationalism. ${ }^{33}$

\section{Upper-Caste Aryanism}

A small but enormously influential book, Bangalir Nritattwik Porichoy [The anthropological identity of Bengalis], was published in 1942. It was a momentous year in South Asia. In August, M. K. Gandhi had asked the British to "quit India" and launched one of the largest mass movements against colonial rule. In response, the British had imprisoned most of the Congress leadership. The Muslim League, which claimed to represent Muslim interests in British India, and the Hindu Mahasabha, which claimed to speak for Hindus, were both opposed to the "Quit India" movement. It was in this fevered political climate and amidst the clash of rival nationalist visions that the Hindu Mahasabha published Bangalir Nritattwik Porichoy that October. The very fact that the Hindu Mahasabha would undertake to publish a work on biometrics in the febrile political climate, just as the debate over the possible partition of India and Bengal was reaching a climax, is enough to testify to the emotional and political charge that biometrics had taken on in the public life of the nation.

The little book's author was Atul Krishna Sur, and he dedicated it to two of his teachers, Haranchandra Chakladar and B. S. Guha. Sur had graduated in ancient Indian history and anthropology before obtaining a Ph.D. in Economics. He taught at the Calcutta University and worked simultaneously on the editorial staff of a leading Bengali newspaper. He wrote more than one hundred and fifty books in his lifetime, many of them about the racial history and identity of Bengalis. ${ }^{34}$ His 1942 publication remained one of his most popular works and was even translated into Hindi in the 1970s. Most significantly for us, Sur's book reopened the public life of biometrics at a time when Mahalanobis and Guha were striving to carve out new cloistered spaces for it.

Sur positioned himself within the tradition of Ramprasad Chanda and Biraja Sankar Guha. He avoided any mention of Mahalanobis and was blunt about the unreliability of Risley's data: "It must be said that the people Sir Herbert Risley had employed in anthropometric work had absolutely no scientific training in anthropometry. He simply trained them in how to take measurements and sent them into the field with the important task of anthropometric

33 Projit Bihari Mukharji, "Profiling the Profiloscope."

34 Atul Sur, Bangla O Bangalir Bibartan (Calcutta: Sahityalok, n.d.), "Lekhak Parichiti." 
work on their shoulders. There are therefore enough grounds to be suspicious

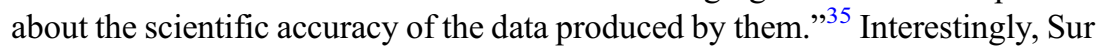
did not seem to mind that Chanda, too, was bereft of any specialized training in anthropometry or anthropology. Be that as it may, in Sur we find crystallizing a position that drew upon Chanda and Guha and was clearly opposed to Mahalanobis' attempts to rehabilitate Risley's work.

Like Chanda before him, Sur was opposed not to Risley's raciology as such, but rather to the conclusions he had arrived at. More specifically, both men contested the designation of upper-caste Bengalis as non-Aryans and sought to prove that they were in fact true Aryans. Sur wrote,

Practically all the upper castes in Bengal possess the characteristic of having broad foreheads ... we know how Risley had been confused by noticing the broad foreheads of the Bengali upper castes. We know that the Bengali upper castes inherited their broad foreheads from the Alpine race. We feel that these Alpine people must have traveled either from Asia Minor or Baluchistan along the coast of the western seas ... it was these Alpine people who were the ancestors of upper caste Bengalis.... Though these Alpine people spoke the Aryan tongue, their language had some differences from the language of the Nordic group of Vedic Aryans who had settled in the Punjab. ${ }^{36}$

The biometric divergence of the Bengali upper castes from the people of the Punjab, which the latter had since Risley's time been seen as the closest to the ancient Aryans, was thus explained by positing two distinctive but equally Aryan founding populations, one Nordic and the other Alpine. They had bifurcated at some point before entering South Asia, but were both equally Aryan.

The Homo Alpinus was first proposed by the French raciologist Georges Vacher de Lapouge, but Chanda picked it up through the writings of T. A. Joyce. $^{37}$ Like Sur, Chanda had denied any direct relationship between Bengali upper castes and north Indian upper castes. ${ }^{38}$ Yet, this did not mean that the Bengali upper castes were autochthons; they were merely descended from a separate branch of the Aryan family tree, namely, the Homo Alpinus. Interestingly, Chanda had also openly challenged the racial distinctiveness of Brahmins in Bengal by describing their likeness to the two other elite Bengali castes: Bengali Kayasthas and Baidyas. ${ }^{39}$ Bengali upper-caste Aryanism, therefore, had certain specific contours. It emphasized the similarities within elite Bengali castes, while distancing them from north Indian upper castes. Instead, they were often posited to have similarities with Marathi and Kannada upper castes, which were also thought to have descended from Homo Alpinus. These upper castes were plainly distinguished from the lower castes of these regions.

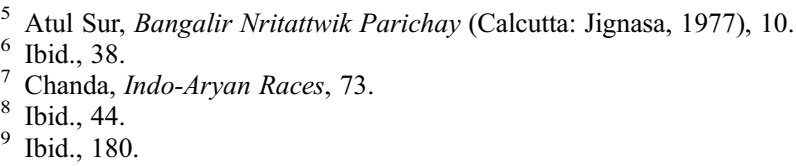


Unlike Chanda and Sur, who wrote for a more public audience and had limited disciplinary training in anthropology, Guha worked squarely within the "cloistered" world of academic anthropology. Predictably, he differed on many points from Chanda and Sur, yet one point he shared with them was in regards to upper-caste Aryanism. Brahmins, "more than any other caste," he argued, "have preserved their original physical characteristics." 40 Writing of Bengal, Guha is once again clear that the upper castes, particularly the Brahmins, are obviously distinct from the rest of the population. Their noses, allegedly, are the sharpest in all of South Asia outside of the Punjab. ${ }^{41}$ However, like Chanda and Sur, Guha had to concede that the upper castes of Bihar and the United Provinces still differed from the Bengali upper castes amongst whom, despite their sharp noses, a different head-type (viz. brachycephalic) predominated. ${ }^{42}$ Despite avoiding the term Homo Alpinus, Guha's framework was similar to that used by Chanda and Sur. For him, too, there was an obvious and visible divergence between Bengali upper castes and lower castes, and the former were patently Aryan. Still, they were not identical with north Indian upper castes. What Guha added to Chanda and Sur was an argument about ethno-geographic variations within the Bengal region. All this served to undermine the racial, and therefore national homogeneity of the region, and instead it emphasized the distinctiveness and social prestige of the upper castes.

Guha's absolute faith in the racial separation of upper and lower castes was expressed in the most unambiguous terms when he mocked J. C. Nesfield, who had proposed a non-racial theory of caste: "Mr Nesfield's power of observation can be best judged from the fact that according to him 'no observer could now distinguish members of the higher castes (in India) from the scavengers who sweep the roads." "43 For Guha, the racial divide between upper and lower castes was obvious and anyone who failed to see it was a poor observer.

Upper-caste Aryanism also impelled its most trenchant promoters to be singularly critical of Risley. Though they worked within the same anthropometric tradition, much of their work was devoted to refuting Risley since he had denied the existence of any Aryan element in Bengal. Guha wrote, for instance, that Risley's material had "doubtful comparative value." 44 Aside from such frontal attacks on Risley's data, Guha throughout his thesis snipped at Risley's Indian subordinates as a way of undermining that data. Regarding Risley's Kashmir data, Guha faulted him for depending on a "Mohamedan" called Alauddin, which led to the "proud" Kashmiri Brahmins being left out

\footnotetext{
40 Biraja Sankar Guha, "The Racial Basis of the Caste System of India," PhD thesis, Harvard University, 1924, 45.

41 Ibid., 121.

42 Ibid., 121.

43 Ibid., 103.

44 Ibid., 234.
} 
of the data set. Concerning the United Provinces, Risley was criticized for having relied on one Chandi Singh, whose "scholastic attainments," Guha felt, were of an "extremely dubious character." 45 Later, Sur repeated this line of attack: "It must be said that the employees of the Ethnography Department that Sir Herbert Risley deployed to make the anthropometric measurements lacked any specialized training in anthropology... As a result there are enough grounds to be doubtful of the scientific value of the measurements they took." 46 Such denunciations of Risley ran completely counter to the tradition inaugurated by Mahalanobis, wherein he argued, "The real defect in Risley's data creeped [sic] in during the calculation of average values, and ... his primary data of individual measurements can be used with safety...."47

Tony Ballantyne has argued that while British Orientalist scholarship and particularly its Aryanism were crucial to the constitution of modern Hindu nationalism, there were significant variations in how different Hindu nationalists deployed Aryanism: "For some it was a vehicle for stressing kinship with the British rulers and praising the gifts of the Raj, for others it was an inclusive term which was to underpin their vision of Indian nationalism, and for others still it was a tool to inscribe rigid lines between communities, to offer a narrow and particularizing definition of their racial and religious identity." These are fascinating insights, but one nuance of Hindu Aryanism that has escaped attention is how it split the category "Aryan" itself into different types-Nordic, Alpine, and so forth.

Such distinctions were particularly useful in Bengal, where the relationship between the "Indian" and the "Bengali" identities remained ill-defined and ambiguous throughout the better part of the anticolonial struggle. On one hand, Bengali intellectuals played an important part in developing Indian and Hindu nationalism underwritten by Aryanism. On the other, many of these same intellectuals were proud of their distinctive Bengali identity and distinguished it from the larger, and especially north Indian, Hindustani identity. The Nordic and the Alpine Aryanisms allowed this ambiguity to be sustained at the racial level.

Notwithstanding such inflexions, what is inescapable about the Aryanism that colored the biometric discourse of twentieth-century Bengali intellectuals is its evident links with a racialized Hindu upper-caste identity. Chanda, Guha, and Sur all agreed that the fundamental basis of caste was racial and that upper castes were one type of Aryan or the other. By contrast, Mahalanobis, following Seal, held that races were mutable and therefore shaped by their location.

45 Ibid., 85, 103.

${ }^{46}$ Sur, Bangalir Nritattwik Parichay, 10.

47 Mahalanobis, "Revision of Risley's Anthropometric Data," 104.

48 Tony Ballantyne, Orientalism and Race: Aryanism in the British Empire (Basingstoke: Palgrave McMillan, 2002), 169. 
Hence different castes in the same region resembled each other rather than geographically distant caste-mates. ${ }^{49}$

\section{AESTHETIC NON-ARYANISM}

Upper-caste Aryanism may have been rampant in the Bengali biometric discourse, but it did not go unchallenged in public life. Mahalanobis' effort to displace this casted Aryanism with his own, distinctly regionalist biometric nationalism was not alone in rejecting it. A more fulsome challenge was mounted by those who wholly ignored the claims of biometricians to determine the racial identity of the Bengalis. These intellectuals sought the basis of racial identity in cultural practices rather than in the biological body. For them, racial identity was engendered in an archive of cultural practices, and particularly in craft objects, rather than in body morphology.

This culture-centric and strangely "asomatic" notion of race first began to emerge in the work of Gurusaday Dutt (1882-1941). Born in Sylhet, Dutt was a brilliant student who placed first in the First Arts Examinations before traveling to England in order to enter the Indian Civil Service. There he ranked first in the highly competitive Civil Service entrance exams, and also qualified as a barrister. Upon his return to India, Dutt served with distinction as a civil servant for many years. In the late 1920s he became involved with folk arts. During his fourth visit to Britain, in 1929, he attended the All-England Folk Dance Festival at the Royal Albert Hall. Asok Mitra, in posthumously editing one of Dutt's major works on folk dances of Bengal, wrote, "The Festival became the historian of his memories. The festivals of his village, the toys, pictures and objects of art, the dances, all flashed across his mind, and gave him the inward look."50

Returning again to India, Dutt set about establishing a number of organizations for the revival, study, and appreciation of Bengal's (and to some extent India's) folk heritage, one of the first being The Rural Preservation Society of Bengal, established in 1931. Subsequently he tried to align preservation work with a youth movement called the Bratachari Movement. ${ }^{51}$ Many later Bengali stalwarts, including Sheikh Mujibur Rahman, the first president of independent Bangladesh, were involved with this movement in their youth and embraced its message of physical culture and earthy Bengali nationalism built on an appreciation of Bengali folk heritage. Besides his organizational work, Dutt was an avid collector of folk arts and his collections and exhibitions introduced many of Bengal's intellectual elites to the regions' rural heritage. In a little over a decade, between his return from his 1929 London trip and his death, he

49 Mahalanobis, "Analysis of Race Mixture," 311.

50 Asok Mitra, "Preface," in Gurusaday Dutt, The Folk Dances of Bengal (Calcutta: Birendrasaday Dutt, 1941), vi-vii.

${ }^{51}$ For a recent history of the Bratachari Movement, see Sayantani Adhikary, "The Bratachari Movement and the Invention of a 'Folk Tradition,"' South Asia 38, 4 (2015): 656-70. 
collected over two and half thousand "folk" art objects, ranging from textiles to woodwork, paintings, metalwork, pottery, jewelry, and much else. Eventually he established a museum to house his collection. ${ }^{52}$

Like the exponents of upper-caste Aryanism, Dutt believed in a fundamental divide within Indian and/or Hindu-Bengali culture. They all agreed that the religion and culture of the upper castes were significantly different from the religion and culture of the lower castes. The upper strata they repeatedly identified with a prehistoric "Aryan" heritage, while the lower strata were of non-Aryan vintage. Where Dutt differed was in his valuation of upper-caste Aryanism - while those writing within Chanda's biometric tradition valorized what they saw to be an upper-caste Aryan culture uniting the Bengali upper castes with other pan-Indian upper castes, Dutt valued more the rustic, lower-caste-based, and, according to him, "non-Aryan" culture and religion. Expressing his historical views, he wrote:

The form of Hinduism practiced by Bengal's popular/national race (Banglar ganajati) has always been quite distinct from the religion of the Brahmins. The habitually irrepressibly independent soul of the Bengalis could not slavishly follow the scriptural injunctions.... That despite the oppression by the Brahmins and [Brahminic] society, these national devotees, saints, and artists did not surrender their national mentality and aesthetic, is a glowing testament to the irrepressible love for freedom in our national race. $^{53}$

I call this position an "aesthetic non-Aryanism."

At a time when Aryanism was highly valued amongst Indian intellectuals and nationalists, and particularly Hindu nationalists, Dutt and those he influenced asserted a strident and confident non-Aryanism grounded in an appreciation of folk arts. ${ }^{54}$ The basis of this non-Aryanism was the aesthetic value ascribed to folk arts and crafts. This aesthetic non-Aryanism was distinct from the Dravidianism that developed in Tamil-speaking regions. ${ }^{55}$ The proponents of aesthetic non-Aryanism were seldom themselves from lower castes and they did not putatively attack Brahmins. Instead, they sought to argue that Bengali culture was heavily indebted to non-Aryan contributions and that these contributions were clearest in the rustic religious life of the lowercaste Bengali peasantry. But Bengali aesthetic non-Aryanism's most prominent divergence from Dravidianism was its dependence on the study and appreciation of folk arts and artifacts.

In 1932, Dutt organized an exhibition in Calcutta to which he invited some of the most important intellectuals of the day. Those who attended and, according to Dutt, were transformed by what they saw, included the famous painter

${ }^{52}$ Gurusaday Dutt, Banglar Lokshilpa O Loknritya (Calcutta: Chhatim Books, 2000).

${ }^{53}$ Ibid., 8-9.

${ }_{55}^{54}$ Ballantyne, Orientalism and Race, 169-87.

55 Thomas R. Trautmann, Languages and Nations: Conversations in Colonial South India (Berkeley: University of California Press, 2006), 186-211. 
and folk art enthusiast Abanindranath Tagore, historian Dineshchandra Sen, linguist Sunitikumar Chatterji, and the editor of the influential Modern Review, Ramananda Chatterji. ${ }^{56}$

Young men who were in the Bratachari Movement in their youth recall Dutt's enthusiasm about Dineshchandra Sen's book Brihat Banga [Great Bengal]. Dipesh Chakrabarty has described how, by the time it was published in the 1930s, Sen had lost his once-preeminent position as an academic historian. Dismissed by a later generation of "scientific" historians as a hopeless romantic, Sen sought to delve into what Chakrabarty calls a "romantic archive." 57 This was an archive of, not the textual documents, archaeological objects, and coins that the "scientific historians" held so dear, but rather the everyday rusticity that Sen sought out. This archive, which Sen lovingly mined, included a vast array of folk arts including paintings, story-scrolls (pot), pottery, embroidered quilts (nakshi kantha), and dolls.

In the lengthy introduction to Brihat Banga, Sen expressed his debt to Dutt; not only had he gained his knowledge of folk dances through conversations with Dutt, but he also asserted that it was Dutt who had elevated the status of Bengali folk arts in general. "Abanindranath Tagore, Nandalal Bose, and Jamini Roy were undoubted pioneers in the field, but they were busy with their paintbrushes. It was left to Mr. Gurusaday Dutt, through his researches and lecturing at various places about Bengal's authentic artistic heritage, to reveal the origins of Bengal's living artistic traditions." 58 To be fair, Sen did not really subscribe to the strong non-Aryanism of Dutt. He argued that one could find the last remnants of the true Aryan culture in Bengali villages, ${ }^{59}$ yet Sen agreed with Dutt that it was among the lowest strata of Bengali Hindu society that the truly authentic ingredients of Bengali culture were to be found. ${ }^{60}$

Abanindranath Tagore was more forthright in his non-Aryanism. As Sen pointed out, Abanindranath, alongside contemporary artists like Nandalal Bose and Jamini Roy, had already undertaken an artistic movement inspired by rustic folk arts. Eschewing the refined high-cultural styles, they sought to reinvent a new Bengali artistic tradition based upon the simplicity of folk art. But Abanindranath was not satisfied to remain "busy with his paintbrush," and he soon undertook the formal collection and study of two specific genres of Bengali folk arts: ritual floor illustrations called alpona, and the ritual art and rhymes that were performed during a form of pious observances called bratas. Both

56 Dutt, Banglar Lokshilpa, 3.

57 Dipesh Chakrabarty, "Romantic Archive: Literature and the Politics of Identity in Bengal," Critical Inquiry 30, 3 (2004): 654-82.

58 Dineshchandra Sen, Brihat Banga: Suprachin Kal Haite Palashir Juddha (Calcutta: Calcutta University, 1935), ii.vi.

59 Ibid., xiii.

60 Ibid., ii.viii. 
forms were usually practiced by women of the household and, though religious in nature, neither involved the participation of Brahmin priests. Abanindranath expressed the same aesthetic non-Aryanism we see in Dutt:

On one hand, we have the immigrant Aryans with their religious festivals, on the other, we have the resident non-Aryans with the bratas; the first group lived in the pious hermitages in forests, the latter lived in their riparian motherland tucked away in nondescript villages; in the midst of these two was the Hindu nation.... The history of the Vedas, the Puranas, and what is older than all that, namely these bratas, testifies to one thing - on two sides were two mammoth races and their life stories, in their midst was a group [of common people] and its dreams. ${ }^{61}$

Although Abanindranath seems less confrontational than Dutt, his basic argument and moral valuation are very similar. Both men hold that both Aryans and non-Aryans have contributed to the creation of a Bengali Hindu culture, and that what is truly or authentically Bengali comes from the non-Aryan side. It is this pride in the non-Aryan heritage and its location in art and aesthetics that marks out both authors.

This swirling, aesthetic non-Aryanism received its full-blown form in the Africanism of Sunitikumar Chatterji. Today, Chatterji is remembered largely as a historical linguist who wrote extensively on Bengali and other vernacular languages. Yet he also had an enduring love for folk art, which he wrote had arisen in 1919 when he attended an exhibition of African and particularly Congolese art in London. This love of folk African art also instigated for Chatterji a lasting love for Africa itself. In 1960, only four years after Ray proposed his theory of the Bengali Pharaoh, Chatterji published a book titled Africanism. Sarvepalli Radhakrishnan, then vice-president of India and soon to be its president, stated in a foreword to Chatterji's treatise that Africanism drew "attention to the past achievements and future possibilities of the African peoples, the black ones. ${ }^{, 62}$ Chatterji was a resolute humanist who believed in the unity of all humankind, but he emphasized that no such unity could be complete without a recognition of Africa's contribution to it. ${ }^{63} \mathrm{He}$ also mentioned that Black Africans had settled in India in prehistoric times, before being "absorbed or exterminated" by races that came after them (except in places like the Andamans and some places in southern India where they survived independently). Irrespective of the fate of these early African settlers, Chatterji said, "It is believed that some of their religious notions and practices maybe found as a substratum in the cults and religious ideas of the subsequent peoples who established themselves in India...."64

61 Abanindranath Tagore, Banglar Brata (Calcutta: Biswabharati, 1995 [1943]), 8-9.

62 Sarvepalli Radhakrishnan, "Foreword," in Suniti Kumar Chatterji, Africanism: The African Personality (Calcutta: Bengali Publishers Pvt. Ltd., 1960), v.

${ }^{63}$ Suniti Kumar Chatterji, Africanism: The African Personality (Calcutta: Bengali Publishers Pvt. Ltd., 1960), viii.

64 Ibid., 3. 
Chatterji's Africanism echoed certain pan-Africanist trends that sought the origin of African and world civilizations in ancient Egypt. Senegalese panAfricanist Cheikh Anta Diop (1923-1986) began popularizing both the African origins of "civilization" and the centrality of ancient Egypt to African history. His doctoral thesis on the Egyptian origins of African civilizations was rejected by the French academy, but was nonetheless published first in French (1955) and later in English (1974). ${ }^{65}$ While we do not know if Chatterji was directly exposed to Diop's ideas, he would certainly have been aware of the larger pan-Africanist movements.

London was a hotbed of pan-Africanism, especially in the 1920s. That is where the Trinidadian barrister Sylvester Williams first met West African students and began to conceptualize pan-Africanism, and in 1900 he organized the very first Pan-African Conference there. In 1919 and 1921, W.E.B. Du Bois' Pan-African Congresses convened their sessions in London. ${ }^{66}$ Moreover, pan-Africanists based in London, such as George Padmore, were keenly aware of and sympathetic to anti-colonial struggles in British India. ${ }^{67}$ When Chatterji visited the exhibition on Congolese art in London in the 1920s, then, chances are that he encountered an event with strong pan-Africanist resonances.

Chatterji was not alone in India in turning toward Africa at the time. Soon after independence, leading Indian universities introduced programs in African Studies. In 1955, less than a decade after independence, the newly established Jadavpur University in Calcutta was already offering courses on Africa and pan-Africanism in its International Relations program. That same year, Prime Minister Nehru inaugurated a separate African Studies department at the Delhi University with a mandate to promoting greater awareness of Africa. By 1964, some of the new department's faculty had already developed close ties with colleagues in Ghanaian Universities. ${ }^{68}$

Aesthetic non-Aryanism was over-determined by these diverse intellectual and political currents. It emerged in the 1920s and continued to grow through the 1950s and into the 1960s. It created in its wake not only a broader context for the emergence of our Bengali Pharaoh, but also a political and aesthetic challenge to the rising authority of biometric nationalism and upper-caste Aryanism.

As art historian Partha Mitter has rightly written, "The new "ruralism" [evinced by the works of Dutt, Abanindranath, and others] was the particularly Indian expression of the global response to modernity - the romantic longing

\footnotetext{
65 Hakim Adi and Marika Sherwood, Pan-African History: Political Figures from Africa and the Diaspora since 1787 (London: Routledge, 2003): 40-43.

66 Angsu Datta, Utthita Africa (Calcutta: Anandadhara Prakashan, 1967), 127-42.

67 Leslie James, George Padmore and Decolonization from Below: Pan-Africanism, the Cold War, and the End of Empire (Basingstoke: Palgrave Macmillan, 2015), 55, 84, 90, 98, 109.

68 Datta, Utthita Africa, Bhumika [Preface].
} 
of a complex society for the simplicity of premodern existence." ${ }^{\text {"99 }}$ There is little doubt that the new appreciation of folk art that emerged in the 1920s in Bengal was, however loosely, connected with the cult of primitivism that was developing among such avant-garde artists abroad as Pablo Picasso, Henri Matisse, and Amedeo Modigliani. But in India it was much more; its political potential was not limited to a rejection of technocratic modernity-it was also an attempt to resist the somaticization of national identity, and its attendant upper-caste Aryanism, while building stronger global ties with black Africa.

\section{Folkloristics}

One of the key sources for aesthetic non-Aryanism was folkloristics. The emergence of folkloristics in colonial South Asia dated from the second half of the nineteenth century and was intimately tied to a general emergence of ethnography during that period. As David Ludden points out, after the 1857 rebellion British attempts to "know" India emphasized ethnography rather than the study of classical texts. ${ }^{70}$ This, Karuna Mantena observes, coincided with a new phase of liberalism inaugurated by Sir Henry Maine. Maine, Mantena argues, "invented" the notion of a "traditional society," which in order to be administered had to be studied ethnographically. ${ }^{71}$ This new administrative interest in ethnography produced a rich archive made up of gazetteers and settlement reports, and quasi-official journals and monographs authored by colonial civil servants.

Folklore and ethnography are difficult to parse apart in this archive. Many of the district gazetteers, for instance, contain both folklore and ethnographic details, ${ }^{72}$ as do the monographs authored by civil servants such as William Crooke or L.S.S. O'Malley. Not until the emergence of figures like RadcliffeBrown and Malinowski in the interwar period were folklore and ethnography definitively separated. By then, a new domain of the "folk" had long been in public view, distinct from the "classical," the "modern," and the "urban."

Bengali and indeed South Asian elites generally had begun developing an interest in this "folk" domain in the last decades of the nineteenth century. Sadhana Naithani has recently described Ram Gharib Chaube's contribution to Crooke's folklore collections, while Gautam Bhadra has drawn attention to Haraprasad Shastri's redeployment of the Asiatic Society's Sanskrit

69 Partha Mitter, The Triumph of Modernism in India: India's Artists and the Avant-Garde, 1922-1947 (London: Reaktion Books, 2007), 33.

70 David Ludden, "Orientalist Empiricism: Transformations of Colonial Knowledge," in Carol Appadurai Breckenridge, ed., Orientalism and the Postcolonial Predicament (Philadelphia: University of Pennsylvania Press, 1993), 250-78.

71 Karuna Mantena, Alibis of Empire: Henry Maine and the Ends of Liberal Imperialism (Princeton: Princeton University Press, 2010), 155.

${ }^{72}$ For the history of gazetteers, see Projit Bihari Mukharji, "In-Disciplining Jwarasur: The Folk/ Classical Divide and the Transmateriality of Fevers in Colonial Bengal," Indian Economic and Social History Review 50, 3 (2013): 261-88. 
manuscript collection projects toward the acquisition of Bengali folk material. ${ }^{73}$ This new thirst for the "folk" was further encouraged by the emergence of a Bengali literary romanticism that reconstituted "the Bengali village" as a "transcendent idyll." 74 The romance of the simple, rustic village drew sustenance from the growing angst of an urban lower-middle-class population. ${ }^{75}$ Simultaneously, the advent of new material technologies engendered new possibilities for accessing the "folk." For instance, pioneering folktale collector Dakshinaranjan Mitra Majumdar used the then-novel phonograph to collect the folktales he published. ${ }^{76}$ All of these diverse energies were consolidated with the founding of the Bangiya Sahitya Parishad [the Bengali Literary Association] in 1906, which gave institutional encouragement to ethnographic studies. $^{77}$

By the 1920s these trends were taking on a concrete disciplinary form. When the University of Calcutta opened a Department of Anthropology in 1921, Saratchandra Mitra (1863-1938), a folklorist with no formal training, was appointed its first professor. ${ }^{78}$ In that same year another autodidact, Saratchandra Roy (1871-1942), founded Man in India, which would become the leading Indian anthropological journal. ${ }^{79}$ Both Mitra and Roy published extensively and never directly disputed the utility of biometrics. But biometrics were either entirely absent from their published studies or pushed to the margins. Unlike the next generation of anthropologists, such as B. S. Guha, folklore and folkways, not biometrics, remained central to the works of Mitra and Roy.

Traumatized by the Nazi embrace of romanticism, leftist intellectuals have been overly hasty in lumping any interest in the "folk" and romanticism into a

\footnotetext{
73 Sadhana Naithani, The Story-Time of the British Empire: Colonial and Postcolonial Folkloristics (Jackson: University of Mississippi Press, 2010); Gautam Bhadra, Nyara Bot-tolaye Jaye Ko Bar? (Calcutta: Chhatim, 2011).

74 Dipesh Chakrabarty, Provincializing Europe: Postcolonial Thought and Historical Difference (Princeton: Princeton University Press, 2000); Peter J. Klaus and Frank J. Korom, Folkloristics and Indian Folklore (Udupi: Mahatma Gandhi Memorial College, 1991), 60-63.

75 Sumit Sarkar, Writing Social History (Delhi: Oxford University Press, 1999).

76 Chandak Sengoopta, The Rays before Satyajit: Creativity and Modernity in Colonial India (Delhi: Oxford University Press, 2016), 220, 245.

77 MN Srinivas, Collected Essays (Delhi: Oxford University Press, 2002).

78 There is some discrepancy in the literature regarding who was the first professor of anthropology in Calcutta. Srinivas for instance, suggests that it was K. P. Chattopadhyay. MN Srinivas and MN Panini, "The Development of Sociology and Social Anthropology in India", Sociological Bulletin 22, 2 (1973): 179-215. I have followed Sankar Sen Gupta in accepting S. C. Mitra as the first. Sen Gupta does, however, say that, owing to persistent ill health, Mitra's impact on the department was small. Sankar Sen Gupta, Folklorists of Bengal: Life Sketches and Biographical Notes (Calcutta: Indian Publications, 1965), 54, and see 53-88.

79 Sangeeta Dasgupta, "Recasting the Oraons and the 'Tribe': Saratchandra Roy's Anthropology," in Patricia Uberoi, Nandini Sundar, and Satish Deshpande, eds., Anthropology in the East: Founders of Indian Sociology and Anthropology (Calcutta: Seagull, 2007), 132-71.
} 
fascist, or at least nationalist assemblage. ${ }^{80}$ Yet, beyond Europe, folkloristics has been tied up with a variety of political programs, including leftist, radical ones. For example, Neilesh Bose recently explored aspects of the complex interplay between folklore, leftist politics, and regional identity in late colonial Bengal, while Peter J. Klaus and Frank Korom pointed out that folkloristics is fundamentally an "international and comparative" discipline. ${ }^{81}$

"Evolutionism" and "diffusionism" were two key axes along which the "international and comparative" dimension of folkloristics was expressed up until the 1930s. "Evolutionism," as Klaus and Korom clarified, did not commence with Darwin and was far from homogenous. What all the varieties of evolutionism did share was a tendency to "account for differences between cultures by encouraging one to see one's own culture as superior to others. It account[ed] for the difference observed to exist between cultures in terms of the advanced state of one's own culture. Other cultures [were] seen as earlier, primitive stages of one's own more advanced culture." ${ }^{82}$ This stagist view of cultural difference encouraged comparisons between multiple cultures and their arrangement into hierarchies. Evolutionist thinking did not simply create hierarchies between the colonized and the colonizer; as the colonized urban elite gradually came to produce their own ethnographies, they created hierarchies that set themselves off from various subaltern groups. Despite evolutionism's general decline, it has continued to thrive in Indian folkloristics departments, producing and sustaining these elite-subaltern cultural orders. ${ }^{83}$

Alongside evolutionism, diffusionism emerged as another powerful tool of comparison. It saw cultural traits as originating in one area and then being diffused or disseminated through the world. Though diffusionism was already on the retreat by the mid-1920s, its chief promoters W.H.R. Rivers, Grafton Elliot Smith, and Will Perry made much of the archaeological discovery of the Indus Valley Civilization. ${ }^{84}$ As Stuart Blackburn observes, the Aryan thesis propounded by evolutionists such as Max Müller had already provided a shared linguistic and racial history that could potentially connect Europe and Asia, and "diffusion theory added the mechanics of literary borrowing" to this mix. ${ }^{85}$ Yet, as Henrika Kuklick has shown, in British anthropology diffusionism attracted few adherents even at the height of its popularity around the time of World War I. Moreover, the two most prominent components of British

\footnotetext{
80 Dipesh Chakrabarty, Habitations of Modernity: Essays in the Wake of Subaltern Studies (Chicago: University of Chicago Press, 2002), 37.

81 Neilesh Bose, Recasting the Region: Language, Culture and Islam in Colonial Bengal (Delhi: Oxford University Press, 2014); Klaus and Korom, Folkloristics, 12.

82 Ibid., 49.

83 Ibid., 66-68.

84 David Paul Crook, Grafton Elliot Smith, Egyptology and the Diffusion of Culture: A Biographical Perspective (Brighton: Sussex Academic Press, 2012), 79.

85 Stuart H. Blackburn, Print, Folklore, and Nationalism in Colonial South India (Hyderabad: Orient Blackswan, 2006), 186.
} 
diffusionism consisted of an interest in the psychological influence of social forms on the individual, and a quite distinctive, normative political theory. ${ }^{86}$ Neither translated effectively to South Asian writers. For them, diffusionism was mainly of a method for working out racial and cultural histories. Early folklorists and anthropologists like Mitra and Roy repeatedly tried to trace the diffusion of particular cultural traits as a form of cultural history. ${ }^{87}$ Notwithstanding such differences, one can hardly miss the similarities between the ideas of early Bengali anthropologists and the Perry-Elliot Smith thesis that all civilization originated in Egypt and was taken from there to the rest of Africa, Asia, and the Americas. ${ }^{88}$

\section{Bengali Egyptomania}

One of the most pervasive yet curiously neglected templates for imagining Bengal's cultural pasts was provided by the widespread popularity of writings about ancient Egypt, which spanned both formal academic and popular genres. In colonial Bengal one encountered the grandeur of ancient Egypt everywhere, from schoolbook history to the theatre. To grapple with the story of the Bengali Pharaoh that I will present in the next section, we must take account of this Bengali Egyptomania.

Egyptology in Europe is usually thought to date from around the 1820s. Recent scholars such as Elliott Colla have pointed out that "ancient Egypt and its material culture have meant many things to many people." ${ }^{89}$ From Neoplatonists and Rosicrucians to modern Egyptian nationalists and Jews, people the world over have deployed Egyptology to their own distinctive ends. There have thus been not one but many Egyptologies, ${ }^{90}$ and that in colonial Bengal developed its own, characteristic tone.

The first Bengali book on modern Egyptology appeared within a decade of the emergence of formal Egyptology in the West. Modern Egyptology's beginning is usually dated from Jean-Francois Champollion's 1822 decipherment of the ancient Egyptian script. Barely eight years later, the Calcutta School Book Society printed Prachin Itihas Samuccaya. Written by James Princep and translated largely by Rev. J. D. Pearson of Chinsurah, this book

\footnotetext{
${ }^{86}$ Henrika Kuklick, The Savage Within: A Social History of British Anthropology, 1885-1945 (Cambridge: Cambridge University Press, 1993), 124.

${ }^{87}$ See for instance, Sarat Chandra Roy, "A Note on the Kolarian Beliefs about Neolithic Celts," Journal of the Anthropological Society of Bombay 14, 6 (1907): 783-90.

${ }^{88}$ Crook, Grafton Elliot Smith, 28, 30-31, 59.

89 Elliott Colla, Conflicted Antiquities: Egyptology, Egyptomania, Egyptian Modernity (Durham: Duke University Press, 2007), 21.

${ }^{90}$ David Gange, Dialogues with the Dead: Egyptology in British Culture and Religion, 1822 1922 (Oxford: Oxford University Press, 2013); Colla, Conflicted Antiquities; Lindsay J. Ambridge, "Imperialism and Racial Geography in James Henry Breasted's Ancient Times, a History of the Early World," Journal of Egyptian History 5 (2012): 12-33; Lynn Meskell, Object Worlds in Ancient Egypt: Material Biographies Past and Present (Oxford: Berg, 2004).
} 
was printed in both English and Bengali, on alternate pages, and was avowedly based on the works of "Anquetil, Rollin and others.",

Abraham Hyacinthe Anquetil-Duperron was a Frenchman who had lived in India from 1755 to 1761 . Mainly a student of Asian religions, particularly Zorastrianism, he is today remembered mainly for his critique of Montesquieu's "Asiatic despotism" thesis and for having introduced the West to the mysticism of the Upanishads. ${ }^{92}$ An unfortunate spat he had with Sir William Jones had marginalized him in Anglo-Indian scholarly circles. By invoking him, Princep was not only rehabilitating Anquetil-Dupperon's scholarly reputation but also looking back to an older, eighteenth-century genealogy of Anglo-Indian Egyptology. Thomas Trautmann observes that it was only with the decipherment of the hieroglyphics that the relationship between India and Egypt was split asunder in the Orientalist imagination. ${ }^{93}$ Prior to that, in the eighteenth century, the two ancient peoples were seen to have been intimately connected.

Princep's text did not sit alone, since a number of other works, such as a Bengali translation of Robinson's Grammar of History (1832) and Rev. Krishnamohan Banerjea's 1847 translation of Charles Rollin as Ijipt Desher Puravritto [Antiquities of Egypt], ${ }^{94}$ also influenced Bengali Egyptology and hearkened back to the late eighteenth century. That these works were aimed mainly at students and were often included in school curricula augmented their influence on Bengali intellectuals of the next generation. ${ }^{95}$ This textual and curricular Bengali Egyptology contrasts starkly with the origins of British and European Egyptology. Colla has written that the constitution of the "pharaonic artifact" brought back from Egypt was central to the emergence of British Egyptology. 96

The distant and disembodied textual Egypt was made a palpable reality in India not by massive museums but rather by the Anglo-Egyptian War of 1882. As the second city of the now enormous British Empire, Calcutta was awash with reports on and about Egypt. Several Bengalis travelled there as part of the British contingent, usually as clerks, peons, doctors, administrative staff, and the like. One of them was Shyamlal Mitra, who wrote an immensely

\footnotetext{
91 James Princep, ed., Prachin Itihas Samuchchaya: An Epitome of Ancient History (Calcutta: Calcutta School Book Society's Press, 1830).

92 J. G. Manning, The Last Pharaohs: Egypt under the Ptolemies, 305-330 BC (Princeton: Princeton University of Press, 2010), 41; Richard King, Orientalism and Religion: Post-Colonial Theory and the 'Mystic East' (London: Routledge, 1999), 119.

93 Trautmann, Aryans, 15.

94 Robinson's Grammar of History (no author provided) (Calcutta: Indigenous Literary Club, 1832); J. F. Blumhardt, Catalogue of Bengali Printed Books in the Library of the British Museum (London: Trustees of the British Museum, 1886), 54.

95 James Long, Descriptive Catalogue of Bengali Works (Calcutta: Sanders, Cones \& Co., 1855), 25.

96 Colla, Conflicted Antiquities, 27.
} 
successful travelogue, Mishor Jatri Bangali (The Bengali traveler to Egypt) that was serialized in a leading periodical and later released as a book. The book's preface echoed eighteenth-century Egyptology in emphasizing the similarities between Egypt and India: "Like India, Egypt is an ancient civilized country."97

In 1909, Dinendrakumar Ray produced what was possibly the first Bengali attempt at "mummy fiction." Clearly influenced by Mitra's travelogue, his Pishach Purohit (The Zombie Priest) articulated familiar Victorian and Edwardian anxieties about the mummy's curse. On a less familiar note, though, instead of depicting the mummy simply as a threatening Other, Pishach Purohit constantly shuttled between Otherization and identification of the Bengali hero with the "villainous" mummy. At one point the narrator tells us, "Hundreds of years ago, when Europe and America were covered in the darkness of ignorance, when they had no acquaintance with civilization, in that long gone era it was only India in Asia and Egypt in Africa that had ascended to the highest stage of civilization." 98 Later in the novel we hear the back-from-the-dead mummy himself tell the Bengali hero, "You may not know this, but the ancient Hindus and the ancient Egyptians are the same people. They are scions of the same family. They are two branches of the same great tree." 99

No longer was this claim simply an echo of eighteenth-century Egyptology. By 1910, modern Egyptians had begun to claim a pharaonic past for their own nationalist ends, and the mummy's comments seem like a thinly veiled plea for an anti-colonial unity of the ancient civilizations laboring under the British yoke. Israel Gershoni and James Jankowski explain that it was around the turn of the century that Egyptian nationalists began to develop an ideology of "pharaonicism," or al fir'awniyya. This ideology posited a "unique and durable Egyptian national essence persisting from the pharaonic era to the present." 100 This ideology became one of the key "emotional pivots" of Egyptian territorial nationalism. While Egyptian intellectuals strove to disseminate pharaonicism widely through arts and literature, its basis was a racialized understanding of biological unity with the pharaonic era. Salama Musa, one of the leading proponents of the biological unity of ancient and modern Egyptians, repeatedly deployed exactly the same images of the "family" and "family unity" that we find in Ray's novel. ${ }^{101}$

World War I, as had the Anglo-Egyptian War in 1882, again deepened Bengali interest in Egypt. As significant numbers of Bengali officials, clerks,

97 Shyamlal Mitra, Mishor Jatri Bangali (Calcutta: Adityakumar Chattopadhyay, 1884), i.

98 Dinendrakumar Ray, Pishach Purohit (Meherpur: Dinendrakumar Ray, 1910), 50.

99 Ibid., 99.

100 Israel Gershoni and James P Jankowski, Egypt, Islam and the Arabs: The Search for Egyptian Nationhood, 1900-1930 (New York: Oxford University Press, 1986), 164.

101 Ibid., 165. 
and doctors once more traveled there as part of the British war effort, Egyptian news and history grew in importance. The leading Calcutta daily newspaper, the Amrita Bazar Patrika, frequently interspersed its war reporting with snippets of academic and popular histories of pharaonic antiquities in the immediate surroundings of the military conflict. In February 1915, for instance, the Patrika printed a brief report entitled "The Story of Kantara" amidst the war reports. In it, Flinders Petrie's discoveries of a pharaonic palace in the immediate vicinity of the fighting was mentioned alongside the fact that Kantara had for centuries been a "bridge" between Asia and Africa. ${ }^{102}$

By the war's end popular Bengali Egyptomania was obviously growing, and the Minerva Theatre in Calcutta advertised a lavish new production entitled Mishor Kumari (The Egyptian girl). The advertisement announced that the "epoch-making new drama in five acts" would show "the glories of the forgotten past ... the wonderful temple of god Amonra, the mighty pharaoh's matchless palace, the cataract of the Nile, the pyramids with their myriads of wonderful sphinxes...."103 The play ran from May 1919 to at least December 1922 (records are missing for after that) and its advertisements soon carried a long, personalized, handwritten endorsement from none other than Abanindranath Tagore. ${ }^{104}$ Howard Carter's November 1922 discovery of Tutankhamun's tomb added to Egyptomania; it was widely reported in the local press, and as one reporter put it, "illuminate[d] more of the Pharaonic splendor with amazing brilliance and reveals that the Egyptian soared to the world's record height of civilization." 105

In 1926, Abanindranath's famous uncle, Rabindranath Tagore, visited Egypt for the second time, having traveled there as a boy with his father. This time he made close contacts with Egyptian intellectuals. Even before this more intellectually engaged trip Egypt had begun to fascinate the poet. He wrote movingly in 1922 about Egypt from his ship as he traveled to Europe. There, Tagore turned Egypt and Arabia into two idealized and opposing tropes, standing respectively for the "spirit of harmony" and the "spirit of conquest." While he asserted that both spirits were necessary to human life and civilization, he obviously identified more strongly with Egypt's "spirit of harmony," wherein he believed man had achieved greatness without cutting himself off from or trying to dominate nature. ${ }^{106}$

Bengali Egyptophillia continued to grow apace during the decade that followed. As the 1920s drew to a close, a Tamil intellectual based in Lucknow

\footnotetext{
102 "The Story of Kantara," Amrita Bazar Patrika, 19 Feb. 1915: 4.

103 U. K. Mitter, "Minerva Theatre," Amrita Bazar Patrika, 23 Dec. 1919: 9.

104 U. K. Mitter, "Minerva Theatre," Amrita Bazar Patrika, 16 Aug. 1919: 3. The last advertisement for Mishar Kumari that I have been able to trace appeared in Amrita Bazar Patrika, 2 Dec.

105 "Remarkable Egyptian Discovery: Last Tomb of Pharaoh," Leader, 25 Dec. 1922: 4.

106 Rabindranath Tagore, Creative Unity (New York: Macmillan, 1922), 60-61.
} 1922: 3 . 
wrote a two-volume work in English arguing at length that the Pharaoh Ramses II was actually the Hindu epic hero Rama. ${ }^{107}$ While many Bengalis no doubt read the book, many more would have read a pulp novel Morar Mrityu [Death of a corpse] by Hemendrakumar Roy, one of the best-known authors of Bengali adventure fiction. Roy told the story of a Bengali Egyptologist who discovered an ancient Egyptian formula to revive mummies and use them to do his bidding. He employed these zombies to torment anyone who had displeased him. ${ }^{108}$ Roy also penned a short story about a Bengali tourist to Egypt who buys a mummified human leg only to then be haunted by the mummy's ghost at his home in Calcutta. ${ }^{109}$ It was in this climate that the Bengali Pharaoh made his appearance.

\section{Pan-Egyptianism}

Aesthetic anti-Aryanism, folkloristics and diffusionism, and Bengali Egyptomania all came together to create a radically alternate vision of Bengali racial and cultural history. This vision was engendered in the figure of the Bengali Pharaoh and completely ignored biometric nationalism and its somaticized claims to represent Bengali history and identity.

In 1951, independent India conducted its first census as a postcolonial nation-state. The State of West Bengal, now severed from the rest of the historic and cultural region of Bengal, had existed for only three years, and the issue of Bengali identity was still hotly contested. One of the unnumbered volumes of the 1951 census, Tribes and Castes of West Bengal, addressed this issue head-on. $^{110}$

Edited by provincial Census Commissioner Asok Mitra, the volume was comprised of four independent essays and some extracts from older authors on the subject, including Risley. The new essays pulled in different directions. Two of them, both titled "The Racial Composition of Bengalees," sought to align the two dominant forms of biometric nationalism, associated with Mahalanobis and Guha, respectively. ${ }^{11}$ The volume then went on to reproduce Risley's measurement tables at length along with both Mahalanobis' corrections and Guha's additional measurements. ${ }^{112}$

${ }^{107}$ Malladi Venkata Ratnam, Rama, The Greatest Pharaoh of Egypt (Rajahmundry: n.p., 1934).

${ }^{108}$ Hemendrakumar Roy, Morar Mrityu (Calcutta: Eastern Law House, 1939).

109 Hemendrakumar Roy, "Pepir Dakshin Pad," in Gita Dutta, ed., Hemendrakumar Roy, vol. 26 (Asia Publishing Company, Calcutta, 2013), 125-30.

${ }_{110}$ A. Mitra, ed., Tribes and Castes of West Bengal (Calcutta: West Bengal Government Press, 1953).

${ }^{111}$ K. P. Chattopadhyay, "The Racial Composition of the Bengalees"; and Sailendra Nath Sengupta, "The Racial Composition of the Bengalees-A Further Note," both in A. Mitra, ed., Tribes and Castes of West Bengal (Calcutta: West Bengal Government Press, 1953), 365-74, and 375-89, respectively.

112 Mitra, Tribes and Castes, 390-405. 
But the fourth essay, "The Artisan Castes of West Bengal and Their Crafts," took things in a completely novel direction. ${ }^{113}$ Authored by Sudhansu Kumar Ray, it was more akin to an independent treatise. Mitra's foreword to it stated that Ray was well known in Bengali intellectual circles and possessed an unparalleled knowledge of Bengali folk arts. ${ }^{114}$ Ray's essay was not only rich in detail, but also proposed a new historical method for recovering the origins of the Bengali identity.

He suggested that folk arts and artifacts were effectively an archive of a remote history. Thus ritual diagrams called alponas were ancient irrigation maps, while the complex ritual art of the Sejuti Brata depicted Bengal's marshy ecological past. He repeatedly drew attention to striking similarities between southern Bengali folk art and classical Egyptian artifacts. A certain twin-pigeon motif common amongst southern Bengali potters and carpenters, for instance, was said to be identical to the "bowl-head pillars of Egypt." Images and legends of the Dakshin Dwar (Door of the South) were said to closely resemble legends and images of ancient Egypt. ${ }^{115}$ In another ritual Ray found parallels with Egyptian festivals memorializing ancient conquests. $^{116}$

Five years later, in 1956, Ray, then a junior field officer at the Crafts Museum in New Delhi, published a short book in which he formally proposed the founding of the new discipline of "craftology." It was also in this slim volume that Ray first suggested that the many similarities between southern Bengali folk art and ancient Egyptian art evidenced an actual racial connection between the two peoples.

Ray claimed that Akhenaten and his successor Smenkhkare, the two powerful monarchs of the eighteenth dynasty of Egypt, lay buried somewhere in the Rajmahal Hills of West Bengal. Driven out by the orthodox worshippers of Amon sometime between 1358 and $1355 \mathrm{BC}$, these pharaohs themselves, or their followers carrying their mummies, arrived in lower Bengal, Ray said, and it was from these ancient Egyptians that southern Bengal derived its distinctive linguistic and cultural identity. ${ }^{117}$

Ray's purported discovery was intimately tied up with the discipline he was attempting to found. Describing craftology as a "new science," he argued that "it throws much light on the unknown history of a nation."

113 Sudhansu Kumar Ray, "The Artisan Castes of West Bengal and Their Crafts," in A. Mitra, ed., Tribes and Castes of West Bengal (Calcutta: West Bengal Government Press, 1953), 293-350.

114 A. Mitra, "Note": n.p.

115 Ray, "Artisan Castes," 301.

116 Ibid., 306.

117 Sudhansu Kumar Ray, Prehistoric India and Ancient Egypt: Artistic, Linguistic and Political Relations, Revealed by the Bengali Traditional Documents (New Delhi: Cambridge Book and Stationery Store (1956), 12.

118 Ibid., 3. 
key methodology was the comparison of folk and historical artifacts. While Ray admitted the importance of archaeology, he stated plainly that "archaeology must follow Craftology." 119 The major difference between the two was that whereas archeology studied artifacts by extrapolating them from their location, craftology explored artifacts within their lived and performative contexts.

More importantly for our discussion of race is that craftology completely ignored biometric nationalism. In Ray's hands, "asomatic" racial history became a reality. Instead of merely speaking of cultural forms being diffused, Ray was arguing for the racial diffusion of Egyptians to lower Bengal, but, stunningly, was doing so without any reference to physical likeness. Race became something to be derived from cultural artifacts and not bodily similarities.

Ray's intellectual influences were all too clear. He was widely known to be Gurusaday Dutt's protégé and had become interested in folk arts through Dutt. ${ }^{120}$ Later authors commented also on his proximity to Abanindranath Tagore, ${ }^{121}$ while he himself cited Sunitikumar Chatterji and Dineshchandra Sen. ${ }^{122}$ On the Egyptology side, Ray acknowledged his enormous debt to the works of Sir Flinders Petrie and H. R. Hall. Though he had never met these scholars, he invoked a figure in the Mahabharata and called himself their "ekalavya-disciple"; that is, a disciple who learns from a teacher without the teacher's knowledge.

Ray's pan-Egyptianism resonated with the larger political context of the times. The 1950s in India were marked by much public hope for Afro-Asian solidarity. In April 1955, the Bandung Conference gave substance to these abstract hopes. Egyptian President Gamal Abdel Nasser attended, and emerged, alongside Indian Prime Minister Jawaharlal Nehru, as a key proponent of what in time would become the Non-Aligned Movement. ${ }^{123}$ The next year was even more momentous. When a crisis broke out over Nasser's nationalization of the Suez Canal, Nehru initially tried to play a mediating role while taking a definite stand in favor of Egyptian sovereignty. Benjamin Zachariah has written of how the crisis evoked strong passions in India and revived the specter of imperialism. Nehru, riding this popular support, threatened to pull India out of the British Commonwealth. ${ }^{124}$ It was in this Cold War context of India and Egypt forming a strong political alliance that older cultural traditions of identification, such as those engendered in Tagore's writings and his relationships with Egyptian intellectuals, acquired a new resonance.

119 Ibid

120 Ibid., Foreword.

121 Amalendu Mitra, Rarher Samskriti O Dharmathakur (Calcutta: Firma KL Mukhopadhyay, 1972), 51, 94.

${ }_{122}$ Ray, Prehistoric India, 7, 8.

123 Robert McNamara, Britain, Nasser and the Balance of Power in the Middle East, 1952-1977 (London: Taylor \& Francis, 2003), 42.

${ }^{124}$ Benjamin Zachariah, Nehru (London: Routledge, 2004), 222. 


\section{CONCLUSION：VERNACULAR ANTHROPOLOGY}

International scholars rejected Ray's Bengali Pharaoh in the most unambiguous terms. John D. Cooney, an eminent Egyptologist who reviewed the book for the journal Artibus Asiae, dubbed it a "curious book" and said that to encourage any further publications from the author along these lines would be an act of "misplaced kindness." Cooney argued that the ancient Egyptians "were not adventurous, nor were they intellectually curious; there was scant inducement for them to undertake such discomforts and he seriously questioned whether they had the seamanship and vessels for such a journey.", 125

Cooney's unkind review seems to have had an immediate effect. Ray never published the fuller version of his argument that he had promised, of which he had said he had already typed up over four hundred pages in 1956. Yet he did not completely give up on his theory. In 1961, he published another slim book on the ritual art of the bratas in which he reiterated his belief in the Bengali Pharaoh. ${ }^{126}$ For a while that seemed to have been the end of the Bengali Pharaoh.

A decade later, though, in 1972, the publisher of Ray's last work on ritual art released a bulky monograph by a new author, Amalendu Mitra, which revived Ray's theory of Egyptian settlement in Bengal. Mitra's monograph dealt with the Bengali cult of Dharmathakur, ${ }^{127}$ one of the most widely studied regional cults, which had long perplexed ethnologists. It had come to be seen as one of the quintessentially Bengali folk deities. Mitra's work was based on decades of fieldwork and the richness of his field data is beyond question. He had never held an academic job and for years had scoured southwest Bengali villages for every scrap of information he could find. The book was warmly received by Bengali intellectuals and won the prestigious Rabindra Puraskar from the West Bengal government. This critically acclaimed book revived the Bengali Pharaoh.

Not only did Mitra lend the authority of his considerable experience and ethnographic knowledge to supporting Ray's thesis, but he also mentioned that Abanindranath Tagore, a mentor of Mitra, had been preparing a more fulsome defense of Ray's theory with new proofs that he had acquired in research trips to museums in London. ${ }^{128}$ The prize Mitra won, and the fact that, unlike Ray, he had written in Bengali rather than English, ensured that the Bengali Pharaoh got a much broader reception after his revival.

This did not seem to alter the Bengali Pharaoh's fate among international scholars. Rahul Peter Das, a German scholar of Bengali origin, in a lengthy

John D. Cooney, "Sudhansu Kumar Ray," Artibus Asiae 20, 2/3 (1957), 229.

126 Sudhansu Kumar Ray, The Ritual Art of the Bratas of Bengal (Calcutta: Firma KL Mukhopadhyay, 1961).

127 Mitra, Rarher Samskriti.

128 Ibid., 51, 94. 
review of Mitra's book trashed Ray's "unwholesome influence” on Mitra. He called Ray's work “a book full of weird ideas based on incompletely understood popular writings on Egypt and India," and rhetorically asked, "Is it any wonder that many Indian publications are dismissed as not being worth reading by serious scholars"? ${ }^{129}$ Yet Das, like Cooney before him, failed to kill the enthusiasm Bengali scholars displayed for the book. Writing in 1985, for instance, Sriharsa Mallick included Ray's work in a short bibliography of the most relevant works he had consulted in writing a treatise on Bengali folk art. ${ }^{130}$ The following year Akshaykumar Kayal included both Ray and Mitra in a selective bibliography of the most important works on the history and character of the Dharmathakur cult. ${ }^{131}$ In Suhridkumar Bhowmick's small 1990 book on the Aryans we once again find Ray invoked at length. ${ }^{132}$ Writing in 2000, Tarapada Santra still cited Ray extensively in his book on Bengali folk art and artisans. ${ }^{133}$

Beyond these references to Ray's thesis, there is evidence that some of his theories had by the mid-1980s almost become a shared commonsense amongst Bengali vernacular ethnologists. Narottam Haldar's 1988 publication, for instance, argued, "Travel instigated by trade along with the establishment of colonies had led to these exchanges with Egypt; even the cloth used to wrap Egyptian mummies came from Bengal." ${ }^{134}$ Strikingly, the largest part of Haldar's evidence for this claim was identical to evidence Ray had cited. Yet Haldar did not cite Ray. He sourced his evidence to the writings of another, obscure vernacular anthropologist, Purnenduprasad Bhattacharya, which had been published in an equally obscure local periodical.

Despite the utter disdain of international scholars, then, the Bengali Pharaoh has continued to cast his shadow on Bengali authors. This divergence testifies to the very different standards of plausibility and proof that prevail among the two sets of authors. While Cooney and Das reject the Bengali Pharaoh as utterly implausible and born out of poor scholarship, Bengali authors like Mallick, Kayal, and Haldar continue to find accounts of the pharaoh credible and the scholarly arguments in his favor reliable. This marks a distinctive body of scholarship in Bengali that is only partially connected to the mainstream of the international discipline of anthropology.

129 Rahul Peter Das, "Some Remarks on the Bengali Deity Dharma: Its Cult and Study," Anthropos 78, 5/6 (1983): 661-700, 665.

130 Sriharsa Mallick, Prasanga Lokchitrakala (Calcutta: Pustak Bipani, 1985).

131 Akshaykumar Kayal, Rupramer Dharmamangal (Calcutta: Bharbi, 1986): ou.

132 Suhridkumar Bhowmick, Arya Rahasya (Mecheda: Maramburu Press, 1990), 58-60.

133 Tarapada Santra, Pashchimbanger Lokshilpa O Shilpasamaj (Calcutta: Sarkar Enterprise, 2000)

134 Narottam Haldar, Gangaridi: Alochona O Porjalochona (Calcutta: Dey Book Store, 1988), 85 (my italics). 
This Bengali scholarship is produced by scholars who reside on the margins of academia, such as Ray, Mitra, and Haldar. None of these men had full-time academic jobs, yet all had an enormous amount of field experience. For them, the study of folkways was always a way to access a particular racial and cultural history, one that made sense within a political context that operated at both the international and the regional levels. At the regional level their politics favored the non-elite rural masses whose cultural expressions they studied, while at the international level their politics resonated with what is often called the "Spirit of Bandung," a hope of Afro-Asian unity against empire. I call this body of scholarship "vernacular anthropology."

Both the textual references and the methods of this scholarship often seem dated if we adopt disciplinary anthropology as our norm. For instance, etymological word lists that continue to be a favorite tool for our vernacular anthropologists have long been rejected by mainstream anthropology. ${ }^{135}$ Likewise, Mitra and many other vernacular anthropologists continue to rely on James Frazer's nineteenth-century classic The Golden Bough. Such practices bewilder scholars like Das because they are convinced that disciplinary anthropology's norms should apply to this body of scholarship as well. Vernacular anthropology, however, has very different methodological concerns and within it scholarly authority is quite differently constituted.

I contend that the tremendous importance of long, even life-long immersive fieldwork, though it is seldom overtly theorized, gives these vernacular anthropologists a political instinct that frequently impels them to see their work as a technology for empowerment. Their work thus acts not merely to archive a wealth of locally relevant ethnographic information, but also to craft a possible political language of empowerment. Therefore, for them, the scholarly apparatus is not an end in itself, run, as in strictly academic circles, by the simple logic of professional academic protocols. Instead, for vernacular anthropologists the scholarly apparatus is a technology by which they craft a more empowering political identity for their subjects and neighbors.

When Cooney or Das fault vernacular anthropologists for not adhering to the disciplinary protocols of anthropology, they overlook two crucial facts. First, for the vernacular anthropologist, issues of empowerment and academic accuracy may not be as unequivocally segregated as they are for professional anthropologists. Second, much of the space for disciplinary anthropology, whether at the Anthropological Survey of India or the Indian Statistical Institute, has been progressively taken over by biometric nationalism of one kind or another. These biometric nationalisms might fit better with global trends for the re-inscription of race, but their local impact is to naturalize and reinforce existing socio-cultural hierarchies of caste as racial hierarchies between Aryans

135 Trautmann, Languages and Nations, 1-41. 
and non-Aryans or, to use the contemporary terminology, Caucasoids and Protoaustraloids. ${ }^{136}$ Vernacular anthropology's "asomatic" discourse on racial history is radical precisely because it ignores these hegemonic forms of thinking about group-based human difference.

Vernacular anthropology continues to be practiced in Bengal today even as biometric nationalism dominates institutional academic spaces for the "study of man." Even as hallowed, mainstream institutions of excellence such as the Indian Statistical Institute, often unwittingly, produce the most static and reductively racialized images of marginal groups, vernacular anthropology continues in its own seemingly idiosyncratic vein to foster new languages of empowerment by relocating racial history as a history of cultural creativity. While the biometric nationalists look to genes in writing narrow, linear demographic histories, in the hands of today's craftologists - that is, the vernacular anthropologists - folk artifacts become eloquent embodiments of the potentially open-ended, de-somaticized, and cosmopolitan histories of "raced" subalterns.

Abstract: Extant South Asian histories of race, and more specifically biometrics, focus almost exclusively upon the colonial era and especially the nineteenth century. Yet an increasing number of ethnographic accounts observe that Indian scientists have enthusiastically embraced the resurgent raciology engendered by genomic research into human variation. What is sorely lacking is a historical account of how raciology fared in the late colonial and early postcolonial periods, roughly the period between the decline of craniometry and the rise of genomics. It is this history that I explore in this article. I argue that anthropometry, far from being a purely colonial science, was adopted by Indian nationalists quite early on. Various distinctive shades of biometric nationalism publicly competed from the 1920s onward. To counter any sense that biometric nationalism was teleologically inevitable, I contrast it with a radical alternative called "craftology" that emerged on the margins of formal academia amongst scholars practicing what I call "vernacular anthropology." Craftology and biometric nationalism continued to compete, contrast, and selectively entangle with each other until almost the end of the twentieth century.

Key words: race, physical anthropology, genetics, folklore, folk art, non-aligned movement, caste, Pan-Africanism

136 Indian Genome Variation Database Portal; Laura Dudley Jenkins, “Another 'People of India' Project: Colonial and National Anthropology," Journal of Asian Studies 62, 4 (2003): 1143-70. 